\title{
MENINGKATKAN KEMAMPUAN BERBAHASA LISAN ANAK MELALUI MEDIA CERITA BERGAMBAR
}

\author{
Bujuna A. Alhadad \\ Dosen PG-PAUD FKIP Universitas Khairun
}

\begin{abstract}
Language is a tool of communication that is very important in a child's life. Based on the growth and development of children's language product also increased in quantity and complexity. That is why the researcher offers story telling media to improve children language skill. Story telling provides experiences and informations between teacher and early childhood that can be delivered directly or indirectly. This research applied classroom action research with two cycles. The subjects of the research are kindergarten students in Weda consist of 13 students. From this research, it showed that the kindergarten students language skill was improved after the implementation of story telling media in the classroom. It can be seen in the score for each test passing the criteria.
\end{abstract}

Key word: language, storytelling, media

\section{PENDAHULUAN}

\section{Latar Belakang}

Undang-undang Nomor 20 Tahun 2003 tentang Sistem Pendidikan Nasional berkaitan dengan Pendidikan Anak Usia Dini tertulis pada pasal 28 ayat 1 yang berbunyi "Pendidikan Anak Usia Dini diselenggarakan bagi anak sejak lahir sampai dengan enam tahun dan bukan merupakan persyaratan untuk mengikuti pendidikan dasar". Selanjutnya pada Bab 1 pasal 1 ayat 14 ditegaskan bahwa Pendidikan Anak Usia Dini adalah suatu pembinaan yang ditujukan kepada anak sejak lahir sampai dengan usia enam tahun yang dilakukan melalui pemberian rangsangan pendidikan untuk membantu pertumbuhan dan perkembangan jasmani dan rohani agar anak memiliki kesiapan dalam memasuki pendidikan lebih lanjut (Depdiknas,USPN,2004:4).

Pendidikan anak usia dini (PAUD) memiliki beberapa program kegiatan, salah satu program kegiatan yakni Taman Kanak-Kanak (TK) yang kusus melayani anak usia 4-6 tahun. TK merupakan pendidikan awal yang dikenal anak setelah pendidikan dalam keluarga, dan merupakan dasar utama bagi perkembangan anak selanjutnya.Pada hakekatnya anak usia dini memiliki 4 aspek perkembangan yaitu sosial emosional, kognitif, fisik dan bahasa, salah satu aspek perkembangan yang sangat penting untuk dapat berkomunikasi dan dapat hidup bermasyarakat adalah aspek perkembangan bahasa. Berdasarkan perkembangan teknologi sekarang ini dalam berkomunikasi, bahasa merupakan alat yang penting bagi setiap orang.Melalui berbahasa seseorang 
atau anak akan dapat mengembangkan kemampuan bergaul (social skill) dengan orang lain.Anak dapat mengekspresikan pikirannya menggunakan bahasa sehingga orang lain dapat menangkap apa yang dipikirkan oleh anak. Komunikasi antar anak dapat terjalin dengan baik dengan bahasa sehingga anak dapat membangun hubungan sehingga tidak mengherankan bahwa bahasa dianggap sebagai salah satu indikator kesuksesan seorang anak.Anak yang dianggap banyak berbicara, kadang merupakan cerminan anak yang cerdas. Metode bercerita dapat memberikan pengalaman dan informasi antara guru dan anak usia dini tersebut yang dapat disampaikan secara langsung maupun tidak langsung (Moeslichatoen, 1996: 140), Bercerita adalah menuturkan sesuatu yang mengisahkan tentang suatu perbuatan atau kejadian dan disampaikan secara lisan dengan tujuan membagikan pengalaman dan pengetahuan yang di milikinya. Dalam konteks anak usia dini bercerita merupakan upaya untuk mengembangkan kemampuan berbahasa anak melalui pendengaran, penglihahatan dan kemudian menyampaikannya dalam bentuk bercakap-cakap, tanya jawab, demonstrasi atau bercerita kembali apa yang telah didengarnya. Cerita yang dibawakan guru harus menarik dan mengundang perhatian anak dan tidak lepas dari tujuan pendidikan bagi anak TK.Bila isi cerita itu dikaitkan dengan dunia kehidupan anak TK, maka mereka merasa akan mendengarkannya dengan penuh perhatian, dan mudah dapat menangkap isi cerita. Dalam kehidupan anak penuh dengan suka cita, untuk itu anak perlu di berikan cerita yang menarik dengan penuh rasa gembira,lucu dan anak merasa asyik dalam menerima cerita yang diberikan oleh gurunya, kegiatan bercerita di Tk diusahakan menjadi pengalaman yang tak terlupakan karena bersifat unik dan menarik yang menggetarkan perasaan anak dan menjadikan motivasi bagi anak dalam mengikuti cerita sampai selesai.

Bahasa mencakup komunikasi non verbal dan komunikasi verbal serta dapat dipelajari secara teratur tergantung pada kematangan serta kesempatan yang dimiliki seseorang, demikian juga bahasa merupakan landasan seorang anak untuk mempelajari hal-hal lain. Anak akan dapat mengembangkan kemampuannya dalam bidang pengucapan bunyi, menulis, membaca yang sangat mendukung kemampuan keaksaraan di tingkat yang lebih tinggi. Selain alat komunikasi bahasa merupakan sarana yang sangat penting dalam kehidupan anak. Di samping itu bahasa juga merupakan alat untuk menyatakan pikiran dan perasaan kepada orang lain yang sekaligus berfungsi untuk memahami pikiran dan perasaan orang.

Sejalan dengan pertumbuhan dan perkembangan anak, produk bahasa mereka juga meningkat dalam kuantitas, keluasan dan kerumitan. Anak-anak secara bertahap berubah dari melakukan ekspresi menjadi melakukan ekspresi dengan berkomunikasi, yang juga berubah dari komunikasi melalui gerakan menjadi ujaran. Anak usia dini biasanya telah mampu mengembangkan keterampilan berbicara melalui percakapan yang dapat memikat orang lain. Mereka dapat menggunakan bahasa dengan berbagai cara seperti bertanya, berdialog dan bernyanyi.Tk Pembina Negeri Weda merupakan lembaga pendidikan sekolah yang ditujukan untuk anak usia $4-6$ tahun lembaga ini turut serta dalam program pendidikan nasional (PAUD) Pendidikan Anak Usia Dini harus merangsang seluruh aspek perkembangan anak, termasuk kemampuan berbahasa 
anak. Namun kenyataannya menunjukan bahwa kemampuan berbahasa anak kelompok B Tk Pembina Negeri Weda masih rendah yakni terlihat dari keterbatasan bercerita anak secara lisan. Anak cenderung kurang percaya diri dalam menyampaikan pemikirannya secara lisan kepada guru, dan seringnya pemakaian bahasa daerah. Berdasarkan permasalahan tersebut peneliti merasa tertarik untuk melakukan penelitian dengan judul "Meningkatkan Kemampuan Berbahasa Lisan Anak Kelompok B Tk Pembina Weda Melalui Media Cerita Bergambar.

\section{METODE}

\subsection{Subjek Penelitian}

Penelitian dilaksanakan di TK Pembina Negeri Weda Kebupaten Halmahera Tengah, pada Kelas B dengan jumlah 13 siswa yang dilaksanakan pada bulan Mei 2014.

\subsection{Deskripsi PerSiklus}

\section{Perencanaan}

Pada siklus I ini, rencana tindakan yang dibuat adalah: a. Menyusun rencana pembelajaran, b. Menempatkan siswa dalam kelompok-kelompok, c. Menyiapkan materi pembelajaran, $d$. Menyiapkan media pembelajaran serta lembar pengamatan yang akan digunakan pada saat mengamati pembelajaran saat berlangsung.Dalam kegiatan belajar mengajar penulis merencanakan kegiatan dengan membuat jadwal kegiatan dalam siklus I dan siklus II. Dalam pembelajaran guru perlu melakukan perbaikanperbaikan dalam memberikan materi pembelajaran pada anak untuk itu perlu adanya lembar observasi dan lembar penilaian yang dapat menunjang guru agar lebih kreatif dan inovatif dalam menggali kreativitas guru dan anak melalui bercerita dan melakukan perbaikan secara bertahap yaitu dengan kegiatan awal (apersepsi), kegiatan inti dan kegiatan akhir. Kegiatan perbaikan pembelajaran dilakukan aktivitas yang tercantum dalam kegiatan inti RKH 1 dan $\mathrm{RKH}$ 2.Penelitian ini bertujuan untuk mendeskripsikan penggunaan media cerita bergambar guna meningkatkan kemampuan berbahasa lisan pada anak Kelompok B Tk Pembina Negeri Weda untuk itu masalah-masalah yang akan diidentifikasi dari penelitian ini yaitu bagaimana penggunaan media ceritabergambar untuk meningkatkan kemampuan berbahasa lisan anak. Jenis penelitian ini menggunakan metode penelitian tindakan kelas atau yang di kenal dengan (PTK) yaitu suatu penelitian yang dilakukan dalam kelas untuk mengetahui akibat tindakan yang diterapkan pada suatu subjek penelitian di kelas yang terdiri dari dua siklus, masingmasing terdiri dari lima pertemuan.Setiap siklus 1 terdiri dari empat tahapan yaitu: (1). Perencanaan (planning), (2). Pelaksanaan (acting), (3). Pengamatan (observing), dan (4). Refleksi (reflecting). 
2. Pelaksanaan.

Dalam pelaksanaan kegiatan dilakukan Setiap siklus terdiri dari empat tahapan yaitu 1. Rencana tindakan, 2. Pelaksanaan, 3. Observasi, 4. Refleksi, tahap ini dapat diuraikan sebagai berikut: 1) Tahap perencanaan tindakan: Dalam tahap ini peneliti merancang $\mathrm{RKH}$, instrumen penelitian serta alat peraga atau media yang akan digunakan dalam kegiatan bercerita. Dan menentukan observer dan waktu pelaksanaan tindakan oleh siapa dan bagaimana tindakan tersebut dilakukan. 2) Pelaksanaan tindakan: Pada tahap ini merupakan implementasi dari tahap perencanaan yaitu melaksanakan pengajaran di kelas sesuai dengan perencanaan.

3. Pengamatan

Peneliti dan patner (observer) mengamati aktivitas siswa selama pembelajaran berlangsung dengan menggunakan lembar observasi.

4. Refleksi

Hasil yang di peroleh dari ketiga tahap diatas dikumpulkan serta dianalisis kekurangan dan kelebihan sehingga diperoleh hasil refleksi kegiatan yang dapat dijadikan acuan penentuan siklus berikutnya. Selain itu refleksi dilakukan antar guru dan pengamat berdiskusi dan guru memberikan tanggapan tentang apa yang telah dirasakan ketika proses pembelajaran berlangsung. Jika hasilnya tidak baik, masih banyak siswa yang tidak tuntas (> $70 \%$ secara klasikal) maka perlu dilanjutkan di siklus ke II. Kegiatan dalam siklus II dilanjutkan setelah mempelajari hasil refleksi pada siklus I, dan memperbaiki segala kekurangan pada siklus I. Adapun tahapan pada siklus II sama seperti tahapan pada siklus I.

\section{HASIL DAN PEMBAHASAN}

Berdasarkan hasil tindakan yang telah dilakukan dapat dinyatakan bahwa pada siklus I, terdiri dari seluruh anak kelompok B yang berjumlah 13 anak, dalam pengamatan terlihat jumlah anak yang dapat bercerita dengan bantuan (tidak tuntas)sebanyak 10 anak (77\%), dan jumlah anak yang dapat bercerita (tuntas) dengan menggunakan bahasa lisan dengan baik sebanyak 3 anak (23\%). Untuk melihat jelas tingkat keberhasilan anak maka penulis menyajikan hasil keberhasilan anak dalam bentuk tabel berikut ini:

Tabel 3.1 Hasil Kemampuan Bercerita Anak Pada Siklus I

\begin{tabular}{|c|c|c|}
\hline \multirow{2}{*}{ No } & \multicolumn{2}{|c|}{ Keterangan } \\
\cline { 2 - 3 } Urut & $\mathrm{T}$ & $\mathrm{TT}$ \\
\hline 1 & & $\sqrt{ }$ \\
\hline 2 & & $\sqrt{ }$ \\
\hline 3 & $\sqrt{ }$ & \\
\hline 4 & & $\sqrt{ }$ \\
\hline
\end{tabular}




\begin{tabular}{|c|c|c|}
\hline 5 & & $\sqrt{ }$ \\
\hline 6 & & $\sqrt{ }$ \\
\hline 7 & & $\sqrt{ }$ \\
\hline 8 & & $\sqrt{ }$ \\
\hline 9 & & $\sqrt{ }$ \\
\hline 10 & & $\sqrt{ }$ \\
\hline 11 & & $\sqrt{ }$ \\
\hline 12 & $\sqrt{ }$ & \\
\hline 13 & $\sqrt{ }$ & \\
\hline Jum & 3 & 10 \\
\hline
\end{tabular}

Keterangan

$\mathrm{T}$

TT

Jumlah anak yang tuntas

Jumlah anak yang belum tuntas : $10(77 \%)$
: Tuntas

: Tidak Tuntas

: $3(23 \%)$

Secara klasikal

: Belum tuntas

Dari tabel di atas dapat dijelaskan bahwa dalam proses belajar mengajar pada siklus I, diperoleh hasil ketuntasan belajar hanya mencapai $23 \%$. terdapat 10 anak dari 13 anak belum tuntas dalam belajar. Hasil tersebut menunjukkan bahwa pada siklus pertama secara klasikal, anak belum tuntas dalam belajar, dalam hal ini karena anak belum terbiasa dengan bercerita secara lisan, anak terkesan masih takut untuk mengungkapkan cerita. Pada tahap pembelajaran siklus I ini hasilnya belum memuaskan.Persentase anak yang bercerita menggunakan bantuan sedangkan bagi anak yang bercerita menggunakan bahasa lisan masih kurang baik dan memerlukan banyak latihan.Dengan melihat hasil yang tidak memuaskan, maka diputuskan untuk melakukan perbaikan pembelajaran pada tahapan Siklus II.

Berdasarkan data yang di peroleh dari hasil pembelajaran terdapat: jumlah anak yang dapat bercerita dengan bantuan sebanyak 10 anak (77\%), dan jumlah anak yang dapat bercerita dengan menggunakan bahasa lisan dengan baik sebanyak 3 anak $(23 \%)$, berdasarkan data ini maka dilanjutkan ke siklus II untuk perbaikan pembelajaran.Setelah menyelesaikan satu siklus peneliti bersama guru yang bertugas sebagai pengamat melakukan diskusi guna membahas hasil observasi terhadap pelaksanaan tindakan. Dari hasil observasi dan diskusi tersebut selanjutnya dijadikan sebagai bahan refleksi dalam upaya memperbaiki tindakan pada siklus berikutnya. Penilaian observasi untuk guru pada siklus I berdasarkan pada metode bercerita terlihat pada data berikut ini: 
Hasil observasi terhadap guru

a. Guru sudah menyediakan alat bantu belajar

b. Dalam membuka pelajaran sudah ada apersepsi, mengkondisikan kelas

c. Guru sudah menerapkan model pembelajaran yang lebih baik

d. Guru memberikan petunjuk dan penjelasan yang berkaitan dengan materi pembelajaran

e. Guru mengarahkan siswa selama proses belajar mengajar

f. Guru memberikan perhatian ke seluruh anak dan memberi bimbingan kepada siswa yang pasif dengan memberi pertanyaan

g. Guru kurang menggunakan waktu secara efektif dan efisien

h. Guru menutup pembelajaran dengan membuat anak lebih aktif lagi.

Kegiatan pada siklus II dilaksanakan setelah mempelajari hasil refleksi pada siklus I yaitu bagaimana hasilnya, apa kekurangannya, apa akibatnya dan apa yang harus dilakukan selanjutnya. Hal ini dilakukan agar pada siklus II dapat dilaksanakan tindakan yang lebih efektif.

Tabel 3. 2 Data pengamatan aktivitas guru siklus I

\begin{tabular}{|l|c|c|}
\hline \multicolumn{1}{|c|}{ Aspek yang dinilai } & Observer I & Observer II \\
\hline $\begin{array}{l}\text { Kegiatan awal } \\
\text { - Guru menyampaikan salam dan } \\
\text { doa,menyanyi }\end{array}$ & 1 & 1 \\
- Guru menyampaikan tujuan & 1 & 1 \\
- pembelajaran & 1 & 1 \\
\hline - Guru menyampaikan judul cerita & 0 & 1 \\
\hline $\begin{array}{l}\text { Kegiatan Inti } \\
\text { - Menyampaikan cerita dengan } \\
\text { menarik }\end{array}$ & 1 & 1 \\
- Menyampaikan pertanyaan & 1 & 1 \\
- Membimbing anak saat bercerita & 1 & 1 \\
- Membimbing anak agar berani & 1 & 1 \\
\hline dan tangguh & 1 & 9 \\
\hline Kegiatan akhir & 9 & $90 \%$ \\
\hline - Menarik kesimpulan & $90 \%$ & 1 \\
\hline Skor & & 1 \\
\hline Presentase & 1 & 1 \\
\hline
\end{tabular}

Pada tahap pembelajaran siklus I ini hasilnya belum memuaskan.Persentase anak yang bercerita menggunakan bantuan sedangkan bagi anak yang bercerita 
menggunakan bahasa lisan masih kurang baik dan memerlukan banyak latihan.Dengan melihat hasil yang tidak memuaskan, maka diputuskan untuk melakukan perbaikan pembelajaran pada tahapan Siklus II. Berdasarkan data yang di peroleh dari hasil pembelajaran terdapat: jumlah anak yang dapat bercerita dengan bantuan sebanyak 10 anak (77\%), dan jumlah anak yang dapat bercerita dengan menggunakan bahasa lisan dengan baik sebanyak 3 anak (23\%), hal ini dilanjutkan ke siklus II untuk perbaikan pembelajaran. Hasil pembelajaran pada Siklus II ini telah mengalami kemajuan signifikan dengan komparasi sebagai berikut: Jumlah anak yang dapat bercerita dengan bantuan (tidak tuntas) dari 10 anak menjadi 1 anak pada Siklus II atau peningkatan sebesar $69,31 \%$,dan anak yang dapat bercerita dengan menggunakan bahasa lisan yang baik dari 3 anak menjadi 12anak pada siklus II atau terjadi peningkatan sebesar $69,31 \%$. Dalam proses perbaikan pada siklus I, penulis menganalisis masalah yang terjadi dengan cara: 1) Memperjelas materi pembelajaran yang disertai dengan contoh-contoh konkret. 2) Penjelasan juga disertai dengan menyajikan alat bantu yang bisa di mengerti anak, serta memberikan kesempatan yang lebih banyak kepada anak untuk latihan bercerita.

\section{Pengamatan/pengumpulan data/instrumen}

Data penelitian yang diperoleh melalui observasi, dan Instrumen yang digunakan adalah lembar observasi penilaian dan dokumen. Penelitian ini menggunakan hasil analisis data kuantitatif dan kualitatif. Teknik analisis data dihitung dari nilai tiap individu dan nilai rata-rata porsentasi dari keseluruhan komponen penilaian. Hasil penelitian diketahui bahwa penggunaan media cerita bergambar untuk meningkatkan kemampuan berbahasa anak di kelompok B Tk Pembina Negeri Weda.

\section{Refleksi.}

Pada penelitian tindakan kelas (Classroom Action Reseach) ini menggunakan 2 (dua) siklus hal ini dilakukan karena pada siklus II 92,31\% siswa telah tuntas. Masingmasing siklus dilaksanakan dengan melengkapi instrumen atau observasi, siklus pertama dirancang dengan dasar refleksi awal. Selanjutnya siklus kedua didasarkan atas refleksi siklus pertama.Dari hasil analisis masalah di atas, maka penulis merumuskan masalah yang akan dijadikan sebagai bahan perbaikan rumusan itu adalah sebagai berikut:

1. Bagaimana menggunakan media cerita bergambar agar dapat dapat meningkatkan kemampuan berbicara anak di Tk Pembina Negeri Weda.

2. Bagaimana cara menggunakan media cerita bergambar agar anak dapat menangkap pesan-pesan moral dari cerita .

\section{Tahap dalam penelitian}

Untuk memperoleh model pembelajaran yang diharapkan yang dapat meningkatkan prestasi belajar anak-anak di Tk Pembina Negeri Weda, diperlukan adanya prosedur kerja yang dipandang sebagai suatu siklus yang di mulai dari perencanaan, tindakan, observasi, dan refleksi tahap tersebut dapat diuraikan sebagai berikut: 


\section{Siklus 1}

1. Tahap Perencanaan Tindakan (planning)

Dalam tahap ini peneliti menyusun Rencana Kegiatan Harian (RKH), dan membuat lembar observasi mengenai peningkatan kemampuan berbahasa melalui media cerita bergambar, instrumen penelitian serta alat bantu dalam bercerita dan menentukan bagaimana tindakan tersebut dilakukan.

\section{Pelaksanaan Tindakan (acting)}

Pada tahap ini merupakan implentasi dari tahap perencanaan yaitu melaksanakan pembelajaran di kelas sesuai dengan proses perencanaan. Pada kegiatan awal guru meminta anak untuk berbaris sebelum memasuki ruangan kelas dan bersiap untuk masuk, dalam ruangan kelas guru memulai dengan salam dan meminta anak-didik untuk berdoa bersama sebelum melaksanakan kegiatan, setelah itu dalam kegiatan inti guru mengemukakan tema yang akan diajarkan pada anak-anak dan menjelaskan tentang aktivitas hari ini pada anak-anak dalam bercerita guru guru dapat membimbing anak dalam pelaksanaan kegiatan bercerita dan mengamati atau observasi pada anak setelah selesai anak di minta untuk cuci tangan dan berdoa sebelum dan sesudah makan kemudian guru meminta anak-anak untuk keluar bermain.

3. Pengamatan (observing)

Peneliti mengamati aktivitas siswa selama pembelajaran berlangsung dengan menggunakan lembar observasi aktivitas siswa dan dilakukan dalam kelas yakni pada saat proses pembelajaran berlangsung. Pengamatan dan pemantauan dilakukan secara komprehensif terhadap pelaksanaan tindakan dan perilaku-perilaku anak dalam mengikuti proses belajar mengajar dengan menggunakan panduan dan instrumen penelitian sehingga diperoleh data-data yang kuantitatif dan kualitatif tentang kemampuan berbahasa.

4. Refleksi (reflecting)

Hasil yang diperoleh dari ketiga di atas dikumpulkan serta dianalisis kekurangan dan kelebihannya sehingga diperoleh hasil refleksi kegiatan yang dapat dijadikan acuan penentuan siklus berikutnya. Selain itu refleksi dilakukan antar guru dan pengamat berdiskusi dan guru memberikan tanggapan tentang apa yang dirasakan ketika proses pembelajaran berlangsung. Untuk memperkuat hasil refleksi kegiatan yang telah dilakukan, digunakan data yang berasal dari hasil observasi. Hasil analisis data yang dilaksanakan dalam tahap ini akan digunakan sebagai acuan untuk merencanakan siklus kedua.

\section{Siklus II}

Berdasarkan hasil refleksi pada siklus I baik yang berkaitan dengan siswa, guru ataupun model pembelajaran maka diadakan perencanaan ulang meliputi kegiatan yang dapat membuat anak nyaman, menciptakan suasana yang akrab, menyusun struktur pembelajaran yang lebih efektif dan mengelolah kelas dengan baik.Kegiatan pada siklus II ini terdiri dari beberapa tahap yaitu:

1. Perencanaan Tindakan 
Pada hasil refleksi yang dilakukan pada siklus pertama maka tahap perencanaan siklus kedua ini dilakukan kegiatan sebagai berikut:

1. Mengidentifikasi faktor-faktor penyebab dan gejala perilaku anak yang mengindikasikan kurang meningkatnya kemampuan bahasa pada anak.

2. Merumuskan kembali tindakan pembelajaran dengan penggunaan media cerita bergambar untuk meningkatkan kemampuan berbahasa anak.

3. Menyusun rancangan tindakan pembelajaran penggunaan kegiatan bercerita.

2. Pelaksanaan Tindakan

Kegiatan yang dilakukan guru pada hari pertama adalah pada kegiatan awal adalah guru meminta anak berbaris memasuki ruangan dengan tertib, guru memulai dengan salam dan doa sebelum melaksanakan kegiatan.

Teknik dalam melaksanakan kegiatan adalah sebagai berikut:

1. Guru mengecek kehadiran anak didik

2. Mengemukakan tema yang diajarkan

3. Menjelaslan kegiatan yang akan dilaksanakan berupa kegiatan bercerita $n$

4. Memberikan contoh setiap kegiatan yang dilaksanakan

5. Memberikan kesempatan pada anak untuk bertanya dan bercerita.

Dalam melaksanakan kegiatan inti ini

1. guru memperlihatkan media yang akan diajarkan

2. memperlihatkan pada anak cara bercerita dengan buku cerita bergambar

3. meminta anak untuk mengikuti apa yang dilakukan guru

Pada kegiatan istirahat guru meminta anak untuk mencuci tangan kemudian berdoa sebelum dan sesudah makan dilanjutkan dengan makan dan setelah itu guru meminta anak untuk bermain. Setelah selesai bermain anak-anak masuk untuk melanjutkan kegiatan akhir dan guru meminta pada anak untuk mengucapkan kalimat thoyibah. Dilanjutkan dengan berdoa untuk pulang dan mengucapkan salam.

3. Pengamatan atau observasi

Pengamatan dilakukan oleh peneliti di dalam kelas, yakni pada saat penyelenggaraan proses pembelajaran oleh guru. Pengamatan dilakukan secara komprehensif terhadap pelaksanaan penelitian tindakan dan perilaku-perilaku anak dalam mengikuti proses belajar mengajar dengan menggunakan panduan dan instrumen yang telah dibuat sebelumnya, sehingga di peroleh data-data kuantitatif dan kualitatif tentang peningkatan kemampuan bahasa pada anak.

4. Refleksi

Setelah guru melakukan kegiatan belajar mengajar pada saat mengadakan pengamatan dan penilaian terhadap keberhasilan belajar anak-anak maka di peroleh data-data baik itu data kuantitatif maupun data kualitatif. Semua data dikumpulkan, dianalisis. Langkah selanjutnya adalah mengadakan refleksi yaitu perenungan terhadap hasil analisis yang dikerjakan dalam penelitian tindakan kelas ini berhasil meningkatkan ketuntasan belajar. Sebagaimana permasalahan yang ada, penulis mengembangkan perbaikan pembelajaran dengan menggunakan media cerita bergambar, dan memberi latihan atau kesempatan bagi anak untuk dapat dengan leluasa mengungkapkan 
ceritanya. Setelah perbaikan pembelajaran pada siklus pertama selesai, maka penulis mendata keberhasilan anak yang dibuat pada tabel siklus II berikut ini:

Tabel 3. 3 Hasil Kemampuan Bercerita Anak Pada Siklus II

\begin{tabular}{|c|c|c|}
\hline \multirow{2}{*}{$\begin{array}{l}\text { No } \\
\text { Urut }\end{array}$} & \multicolumn{2}{|c|}{ Keterangan } \\
\hline & $\mathrm{T}$ & TT \\
\hline 1 & $\sqrt{ }$ & \\
\hline 2 & $\sqrt{ }$ & \\
\hline 3 & $\sqrt{ }$ & \\
\hline 4 & & $\sqrt{ }$ \\
\hline 5 & $\sqrt{ }$ & \\
\hline 6 & $\sqrt{ }$ & \\
\hline 7 & $\sqrt{ }$ & \\
\hline 8 & $\sqrt{ }$ & \\
\hline 9 & $\sqrt{ }$ & \\
\hline 10 & $\sqrt{ }$ & \\
\hline 11 & $\sqrt{ }$ & \\
\hline 12 & $\sqrt{ }$ & \\
\hline 13 & $\sqrt{ }$ & \\
\hline Jum & 12 & 1 \\
\hline
\end{tabular}

Keterangan
$\mathrm{T}$
: Tuntas
TT
: Tidak Tuntas
Jumlah anak yang tuntas
: $12(92,31)$
Jumlah anak yang belum tuntas : $1(7,69)$
Klasikal
: Tuntas

Dari hasil pengamatan yang dilakukan oleh dua orang observer pada guru terlihat dalam kegiatan ini

a. Guru sudah mengorganisir kelompok dan tempat duduk anak .

b. Guru sudah menyiapkan RKH.

c. Guru sudah berusaha merespon pertanyaan dari siswa.

d. Waktu pembelajaran sudah efektif dan efisien. 
e. Memberikan kesempatan pada siswa untuk tanya jawab

f. Memberikan pertanyaan yang variatif selama proses bercerita.

g. Sebagian besar siswa sudah dapat bercerita dengan lisan maupun dengan bantuan.

Penilaian pada siklus II berdasarkan pada metode bercerita terlihat pada tabel berikut ini:

Tabel 3. 4 Data pengamatan aktivitas guru

\begin{tabular}{|c|c|c|}
\hline Aspek yang dinilai & Observer I & Observer II \\
\hline $\begin{array}{l}\text { Kegiatan awal } \\
\text { - Guru menyampaikan salam dan } \\
\text { doa,menyanyi } \\
\text { - Guru menyampaikan tujuan } \\
\text { pembelajaran } \\
\text { - Guru menyampaikan judul cerita } \\
\text { - } \text { Guru menyediakan media }\end{array}$ & $\begin{array}{l}1 \\
1 \\
1 \\
1\end{array}$ & $\begin{array}{l}1 \\
1 \\
1 \\
1\end{array}$ \\
\hline $\begin{array}{l}\text { Kegiatan Inti } \\
\text { - Menyampaikan cerita dengan menarik } \\
\text { - Menyampaikan pertanyaan } \\
\text { - Membimbing anak saat bercerita } \\
\text { - Membimbing anak agar berani dan } \\
\text { tangguh }\end{array}$ & $\begin{array}{l}1 \\
1 \\
1 \\
1\end{array}$ & $\begin{array}{l}1 \\
1 \\
1 \\
1\end{array}$ \\
\hline $\begin{array}{l}\text { Kegiatan akhir } \\
\text { - Menarik kesimpulan } \\
\text { - Melakukan tanya jawab }\end{array}$ & $\begin{array}{l}1 \\
1\end{array}$ & $\begin{array}{l}1 \\
1\end{array}$ \\
\hline Skor & 10 & 10 \\
\hline Presentase & $100 \%$ & $100 \%$ \\
\hline
\end{tabular}

Dari hasil observer terhadap guru dapat lihat dari tabel di atas maka sudah mengalami peningkatan dari $90 \%$ menjadi $100 \%$, hal ini menunjukan bahwa tidak perlu untuk lanjut ke siklus III.

\section{DAFTAR PUSTAKA}

Aisyah, dkk. 2008. Pengembangan dan Konsep Dasar PengembanganAnak Usia Dini. Jakarta: Universitas Terbuka

Asmawati luluk, dkk. 2008. Pengelolaan Kegiatan Pengembangan Anak Usia Dini. Jakarta: Universitas Terbuka 
Depdiknas.2004. Permainan Membaca dan Menulis Di Taman Kanak-Kanak. Jakarta: Depdiknas

Dhieni N et al. 2005. Metode Pengembangan Bahasa. Fakultas Ilmu Pendidikan Universitas Pendidikan Indonesia.

Gunarti Winda. 2011. Metode Pengembangan Perilaku dan Kemampuan Dasar Anak Usia Dini. Jakarta: Universitas Terbuka

Hamalik Oemar. 1994. Proses Belajar Mengajar.Jakarta:PT. Bumi Aksara.

Jalal Fasli. 2002. Stimulasi Otak. Buletin PADU Jurnal Ilmiah Anak Dini Usia

Moeslichatoen. 2004. Metode Pengajaran. Jakarta: Rineka Cipta

Rini Handayani, dkk. 2005. Psikologi Pengembangan Anak. Jakarta: Universitas Terbuka 